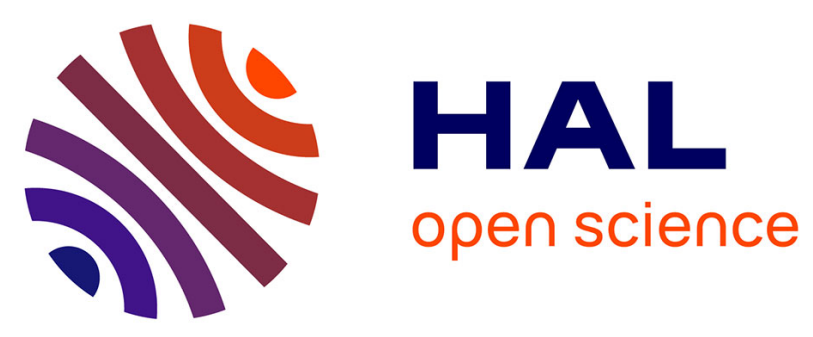

\title{
Subclinical ventricular dysfunction in rheumatoid arthritis
}

\author{
Patrícia Rodrigues, Betânia Ferreira, Tomás Fonseca, Rita Quelhas Costa, \\ Sofia Cabral, João Loureiro Pinto, Francisca Saraiva, António Marinho, \\ Olivier Huttin, Nicolas Girerd, et al.
}

\section{To cite this version:}

Patrícia Rodrigues, Betânia Ferreira, Tomás Fonseca, Rita Quelhas Costa, Sofia Cabral, et al.. Subclinical ventricular dysfunction in rheumatoid arthritis. International Journal of Cardiovascular Imaging, 2020, 37 (3), pp.847-859. 10.1007/s10554-020-02057-3 . hal-03009505

\section{HAL Id: hal-03009505 \\ https://hal.univ-lorraine.fr/hal-03009505}

Submitted on 17 Nov 2020

HAL is a multi-disciplinary open access archive for the deposit and dissemination of scientific research documents, whether they are published or not. The documents may come from teaching and research institutions in France or abroad, or from public or private research centers.
L'archive ouverte pluridisciplinaire HAL, est destinée au dépôt et à la diffusion de documents scientifiques de niveau recherche, publiés ou non, émanant des établissements d'enseignement et de recherche français ou étrangers, des laboratoires publics ou privés. 


\section{Subclinical ventricular dysfunction in rheumatoid arthritis}

Patrícia Rodrigues, MD*1,2,3; Betânia Ferreira, $\mathrm{MD}^{2,3,4}$; Tomás Fonseca, MD ${ }^{5}$; Rita Quelhas Costa, $\mathrm{MD}^{5}$; Sofia Cabral, $\mathrm{MD}^{1,3}$; João Loureiro Pinto, $\mathrm{MD}^{3}$; Francisca Saraiva, $\mathrm{MSc}^{6}$; António Marinho, MD, $\mathrm{PhD}^{5,3}$; Olivier Huttin, MD, $\mathrm{PhD}^{7}$; Nicolas Girerd, MD, $\mathrm{PhD}^{7}$; Erwan Bozec, $\mathrm{PhD}^{7}$; Henrique Cyrne Carvalho, $\mathrm{MD}, \mathrm{PhD}^{1,3}$; João Pedro Ferreira, MD, $\mathrm{PhD}^{6,7}$

${ }^{1}$ Centro Hospitalar Universitário do Porto (Cardiology Department), Porto, Portugal

${ }^{2}$ Unit of Multidisciplinary Research in Biomedicine (UMIB), Porto, Portugal

${ }^{3}$ Instituto de Ciências Biomédicas Abel Salazar, Porto, Portugal

${ }^{4}$ Hospital da Luz Arrábida, Porto, Portugal

${ }^{5}$ Centro Hospitalar Universitário do Porto (Internal Medicine Department), Porto, Portugal

6 Department of Surgery and Physiology, Cardiovascular Research and Development Center, Faculty of Medicine, University of Porto, Portugal

${ }^{7}$ French Clinical Research Infrastructure Network (F-CRIN) Investigation Network InitiativeCardiovascular and Renal Clinical Trialists (INI-CRCT), National Institute of Health and Medical Research (INSERM), Center for Clinical Multidisciplinary Research 1433, INSERM U1116, University of Lorraine, Regional University Hospital of Nancy, Nancy, France

* Corresponding author: Patrícia Rodrigues

Address: Centro Hospitalar Universitário do Porto - Hospital Santo António - Largo Professor Abel Salazar, 4099-001 Porto, Portugal

Email:pfdrodrigues@gmail.com

Phone: (00351)916309981

ORCID ID: https://orcid.org/0000-0003-2147-5913

Short title: Ventricular dysfunction in rheumatoid arthritis

\section{DECLARATIONS}

Authorship: All authors take responsibility for all aspects of the reliability and freedom from bias of the data presented and their discussed interpretation.

Funding: F. A. Saraiva is supported by Universidade do Porto/FMUP and FSE-Fundo Social Europeu, NORTE 2020-Programa Operacional Regional do Norte, NORTE-08-5369FSE-000024-Programas Doutorais.

Conflicts of interest: None declared.

Ethics approval: This study was approved by the Ethics Committee of Centro Hospitalar Universitário do Porto (number 2016-023; 020-DEFI/020-CES).

Consent: All participants gave written informed consent. 


\section{ABSTRACT}

\section{Background}

Patients with rheumatoid arthritis (RA) are at higher risk for developing heart failure. We sought to determine the prevalence of subclinical ventricular dysfunction in RA applying current guidelines, and its association with patients' characteristics, biomarkers and prognosis.

\section{Methods}

Prospective study of RA patients without known heart disease, categorized as preserved ventricular function (PVF), systolic dysfunction (SD), isolated diastolic dysfunction (DD) or indeterminate diastolic function (IDF) as per the 2016 echocardiography guidelines - or any ventricular dysfunction (AVD) comprehending the last 3.

\section{Results}

Median age was 58 years, $78 \%$ females. The majority had PVF (73\%), followed by DD $(13 \%)$, IDF (11\%) and SD (4\%). In 53\%, tricuspid regurgitation velocity could not be determined. Compared with PVF, AVD patients were older (65 vs 55yr, $\mathrm{p}<0.001$ ), had higher prevalence of hypertension and dyslipidaemia (56\% vs $38 \%, p=0.003$ and $60 \%$ vs $41 \%$, $p=0.002$, respectively). Age was the only independent predictor of AVD or DD (particularly $>57 y r$ ). AVD was associated with significantly higher NT-proBNP and lower distance in 6minute walk test.. Concordance with previous guidelines from 2009 was low.

\section{Conclusions}

In a prospective cohort of RA patients without known cardiovascular disease, sSubclinical systolic or diastolic dysfunction was found in 17\% highlighting an important prevalence of cardiac dysfunction is this population. Echocardiographic screening may be of value particularly in RA patients.

Key-words : rheumatoid arthritis; echocardiogram; systolic dysfunction; diastolic dysfunction; biomarkers 


\section{INTRODUCTION}

Rheumatoid arthritis (RA) is a chronic inflammatory disease, involving autoimmune mechanisms, characterized by a symmetric peripheral polyarthritis; however, extra-articular involvement can occur. RA has been associated with heart disease, the pericardium being frequently affected, while coronary artery disease (CAD) and heart failure (HF) (both ischemic and non-ischemic) are also more common than in the general population [1-3].

Regarding cardiovascular (CV) risk prediction in RA patients, the European League Against Rheumatism (EULAR) suggested applying a 1.5 multiplication factor to algorithms conceived for the general population [4] since patients with RA seem to have a two-fold higher incidence of HF and an increased mortality risk [3,5,6]. Although HF with reduced ejection fraction is not particularly frequent, diastolic impairment and left ventricular hypertrophy seem to be more common in RA [7, 8]. Underlying HF aetiologies include atherosclerotic CAD, dilated cardiomyopathy, myocarditis and vasculitis[9]. The role of anti-inflammatory therapies or disease-modifying anti-rheumatic drugs (DMARDs) in heart disease remains unclear [10-13].

RA patients present some specificities [14] and the discrimination of their symptoms is often difficult, since symptoms may be non-specific or conditioned by articular limitations. Therefore, HF could be underdiagnosed in RA patients. Subclinical ventricular dysfunction can be quickly identified by echocardiography, while surrogate biomarkers can be easily studied - other studies have already suggested the prognostic utility of $\mathrm{N}$-terminal prohormone of brain natriuretic peptide (NT-proBNP) [15], C-reactive protein (CRP) and rheumatoid factor (RF) [16, 17]; the value of anti-cyclic citrullinated peptide (anti-CCP) antibodies, erythrocyte sedimentation rate and troponin is more uncertain $[18,19]$.

An earlier diagnosis could improve treatment decisions and consequently prognosis. Noteworthy, the non-invasive diagnosis of diastolic dysfunction - which can be linked to heart failure with preserved ejection fraction[20] - is particularly challenging. A change in echocardiographic guidelines in 2016 reformulated the previous algorithm, with the expectation of a better performance in clinical practice [21, 22].

Prior studies have not focused on subclinical disease following exactly the 2016 guidelines, with a rigorous state-of-the-art homogeneous echocardiographic analysis (most use only one or two parameters and not the complete algorithm and a full assessment of echocardiographic parameters). We will assess a relatively large sample of RA patients, adjust for covariates that were systematically investigated, and complement our analysis with biomarker evaluation. 
Thus, the main objectives of this study are: 1) to assess the prevalence and characterize the type of cardiac dysfunction in RA patients without known heart disease; 2) compare the patients' characteristics according to ventricular function classification; 3 ) analyse biomarker and prognostic associations.

Additionally, we aim to determine the prevalence of a possible precursor stage of heart failure with preserved ejection fraction (HFpEF), using a combination of echocardiographic findings and biomarkers.

Finally, we wanted to compare diastolic dysfunction definitions using the actual 2016 echocardiographic guidelines[22] and the previous guidelines from 2009 [21].

\section{METHODS}

\section{Study Design and Ethics}

Prospective study that enrolled patients followed in the outpatient clinic of Autoimmune Disorders at Centro Hospitalar Universitário do Porto, previously diagnosed with RA, between June 2016 and June 2018. Follow-up was updated in August 2019.

This study was approved by the Hospital's Ethics Committee and was conducted in accordance to the principles of the 1975 Declaration of Helsinki. All participants provided written informed consent before enrollment in the study.

The study was registered in ClinicalTrials.gov under the number NCT03960515.

\section{Patients}

RA diagnosis was made according to 2010 ACR/EULAR Classification Criteria[23]. Patients with an active neoplasm or severe comorbidity, an expected survival of less than 6 months, dementia, inability to walk or totally dependent in their daily life activities were excluded.

For the present analysis, patients with previously known heart disease (HF, CAD, previous percutaneous or surgical coronary revascularization, previous cardiac surgery, at least moderate valve disease, or atrial fibrillation at the time of the echocardiogram) or those that did not perform an echocardiogram were excluded.

Patients were divided into 4 categories of ventricular function, according to transthoracic echocardiogram (TTE) results: preserved ventricular function (PVF); systolic ( \pm diastolic) dysfunction (SD); (isolated) diastolic dysfunction (DD); indeterminate diastolic function (IDF), as defined in Figure 1, following the 2016 European Heart Failure guidelines [20], 2016 guidelines for diastolic evaluation [22] and the 2009 recommendations of the American 
Society of Echocardiography [21]. If half (or more) of the variables needed for each classification were missing, diastolic classification was registered as missing.

We grouped patients with IDF, DD or SD, as per the 2016 guidelines, into one category of "any ventricular dysfunction" (AVD), that was compared with PVF.

Finally, using the 2016 HF European guidelines [20], we also analysed a category of potential subclinical heart failure with preserved ejection fraction (“HFpEF risk"), with the following characteristics: LVEF $\geq 50 \%$ and NT-proBNP $>125 \mathrm{pg} / \mathrm{mL}$ and structural echocardiographic changes (left ventricular hypertrophy or indexed LA volume or diastolic dysfunction as per 2016 echocardiographic guidelines). We use the term "risk" since the presence of signs or symptoms of HF was not mandatory.

\section{Data collection and variables}

Clinical Data

Clinical information was collected and included age, gender, body mass index (BMI), comorbidities, year of diagnosis of RA, Disease Activity Score 28 (DAS28) assessment - that measures disease activity by counting the number of tender or swollen joints [24], combined with the value of erythrocyte sedimentation rate (ESR)- and medication, namely all the medication used for RA and cardiovascular medication.

Transthoracic Echocardiogram (TTE)

Echocardiographic evaluation was analysed by one cardiologist, blinded for clinical information or the results of any other exams, using Philips ${ }^{\circledR}$ iE33 ultrasound machine. To certify the external validity of the echocardiographic measurements, a random sample of 25 anonymized exams was evaluated at the Institut Lorrain du Coeur et des Vaisseaux Louis Mathieu at Nancy, France, and a good correlation of the measurements was obtained (intraclass correlation coefficient $>0.75$ for variables used in diastolic evaluation).

The evaluated parameters included cardiac chambers' dimensions (left atrial and enddiastolic ventricular volumes were calculated using Simpson's rule and were indexed to body surface area), left ventricular wall thickness and mass, left ventricular ejection fraction (using modified Simpson's biplane method), valvular disease, pericardial disease and diastolic function as per the 2016 American and European guidelines [22]. Chamber Quantification European guidelines were followed [25].

\section{Biomarkers}

We analysed the following biomarkers in the hospital lab: NT-proBNP, high-sensitivity troponin $\mathrm{T}$ (hsTnT), C-reactive protein (CRP) and erythrocyte sedimentation rate (ESR). We 
also checked if patients tested positive for anti-CCP antibodies or rheumatoid factor (RF) and their estimated glomerular filtration rate (eGFR).

Exercise Capacity

Patients underwent a 6-minute walk test (6MWT), performed as recommended by the American Thoracic Society [26].

\section{Statistics}

Statistical analyses were performed using STATA version 13 and SPSS ® version 23. A two-sided $p$-value $<0.05$ was used for statistical significance.

Continuous data were described as mean \pm standard deviation or median (IQR - interquartile range between the $25^{\text {th }}$ and $75^{\text {th }}$ quartiles) for gaussian and non-gaussian distributions, respectively. Shapiro-Wilk test for normality was used. Categorical data were presented as absolute frequencies $(n)$ and percentages.

We analysed the relationship between two categories of ventricular function and patients' characteristics using independent-samples $t$ test or Mann-Whitney $U$ test for continuous variables, and Chi-squared or Fisher test for categorical variables, as appropriate. Comparisons between four groups of LV function were done using ANOVA, Kruskal-Wallis tests or multinomial logistic regression.

Linear regression was used to analyse the associations between continuous variables.

Multivariable logistic regression, using categories of ventricular function as dependent variable (taking PVF as reference) was used to estimate independent predictors of ventricular function (covariates with a significant association in the univariable analysis were used in the model), obtaining odds ratio (OR) and the respective 95\% confidence intervals (CI). Hosmer-Lemeshow test was used to determine goodness of fit of model and area under the Receiver Operating Characteristic curve (AUC ROC) to determine its discriminative power.

Cohen's Kappa was used to test the concordance between 2009 and 2016 classifications of diastolic function.

\section{RESULTS}

\section{Baseline characteristics}

For this study, we included 319 RA patients without known heart disease and who performed a detailed TTE (Supplementary Figure 1). 
The median age was 58 years (IQR 19) and 78\% ( $n=249)$ were females. Patients' characteristics are presented in Table 1.

\section{Patients with any ventricular dysfunction (AVD)}

Eighty-seven patients (27\%) had AVD (Table 1); they were older, presented more frequently hypertension, dyslipidaemia, used corticosteroids more often and had lower eGFR. In multivariable analysis (model adjusting for age, hypertension, dyslipidaemia, corticosteroids and eGFR), age was the only independent predictor of AVD (OR 1.079; 95\% CI (1.045; $1.114))$. The area under the ROC curve was $0.71 ; 95 \% \mathrm{Cl}(0.65 ; 0.77)$; best cut-off point in terms of best sum of sensitivity and specificity was 57 years old (sensitivity of $78 \%$ and specificity of $58 \%$ ).

\section{Comparison between categories of ventricular function (using 2016 echocardiographic guidelines)}

Patients with $L V E F \geq 50 \%$, were classified according to the 2016 guidelines - Figure 1 . Tricuspid regurgitation (TR) velocity could be adequately determined in only 151 patients (47\%).

The majority of patients had PVF $(73 \%, n=232)$, isolated DD was documented in 40 patients (13\%) and 34 patients (11\%) had IDF -Table 2. SD was found in $4 \%(n=13)$, being mild (LVEF between 40 and 50\%) in 11 patients and moderate (LVEF between $40 \%$ and $30 \%$ ) in 2 patients.

Age, hypertension and dyslipidaemia were significantly different amongst categories of ventricular function (Table 2).

RA variables, including RA duration, anti-CCP/RF positivity, DAS28-ESR, ESR and RA medication were not associated with TTE results, however corticosteroids were more frequently used in patients with DD and CRP was higher in SD.

In multivariable analysis (adjusting for age, hypertension, dyslipidaemia, corticosteroids and $\mathrm{CRP}$ ), age was the only independent factor associated with categories of ventricular function $(p<0.001)$ - OR for DD (PVF as reference): 1.097, 95\% Cl (1.055; 1.141).

Focusing only on DD category versus PVF, there were significant differences in age, dyslipidaemia, corticosteroid use, eGFR and family history of ischaemic heart disease. In multivariable analysis, age, eGFR and family history were independently related with DD.

\section{"HFpEF risk": combined strategy of echocardiographic evaluation and NT-proBNP}

Excluding those with systolic dysfunction or without NT-proBNP analysis, we identified 40/298 patients (13\%) at "HFpEF risk": with LVEF $\geq 50 \%$ and NT-proBNP > $125 \mathrm{pg} / \mathrm{mL}$ and structural echocardiographic changes [20]. 
After analysis of all covariates in Table 1, age (OR 1.078; $p<0.001$ ), CKD (OR 0.178; $p=$ 0.013), eGFR (OR 0.977; $p=0.005$ ) and RA duration (OR 1.031; $p=0.037$ ) were associated with "HFpEF risk".

On multivariable analysis, age was the only independent predictor of "HFpEP risk".

"HFpEF risk" was associated with ventricular function categories, with $82 \%$ of those without risk having preserved ventricular function (vs 35\% with risk). However, patients with "HFpEF risk" were equally distributed between preserved ventricular function (14/40), indeterminate diastolic function (13/40) and diastolic dysfunction (13/40).

\section{Comparison with 2009 guidelines for diastolic dysfunction classification}

If we applied a simplified model of the 2009 recommendations [21] - Figure 1 - to classify diastolic dysfunction, more patients would fulfil criteria for DD (23\% of the 311 with enough data for comparing both classifications, versus 13\% using 2016 criteria) - Figure 2 and Supplementary Table 1. Interestingly, the percentage of IDF would also be much higher $(47 \%$ vs $11 \%)$. The concordance between both classifications was low (Cohen's Kappa = $0.25)$.

We also analysed specific echocardiographic parameters that can represent structural or functional changes related to HF - Supplementary Table 2 - and tested their association with patients' characteristics - Supplementary Table 3.

\section{Cardiovascular surrogate markers of outcomes}

Since the echocardiographic identification of ventricular dysfunction is more relevant if it is associated with prognosis, we tested the relationship between echocardiographic categories and surrogate prognostic markers.

\section{NT-ProBNP}

NT-proBNP levels were associated with "any ventricular dysfunction" and with the categorization of ventricular function using either 2009 or 2016 guidelines (but were not significantly different between DD and PVF).

NT-proBNP levels were also significantly associated with most echocardiographic parameters (shown in Supplementary Table 3).

Overall, $87 / 311$ patients (28\%) presented NT-proBNP $\geq 125 \mathrm{pg} / \mathrm{mL}$, the cut-off generally set for chronic HF; $34 \%$ of DD and $46 \%$ of SD patients.

\section{hsTnT}


Levels of hsTnT were associated with categories of ventricular function (using 2009 or 2016 classification), but were not significantly associated with having "any ventricular dysfunction" or "HFpEF risk". Log(hsTnT) was associated with having DD versus PVF.

Regarding hsTnT as a dichotomous variable, 25/311 (8\%) patients had a value above normal ( $>0.014 \mathrm{pg} / \mathrm{mL}$ ), but only 2 patients had a value above the cut-off value considered for acute coronary syndrome at our laboratory $(>0.054 \mathrm{pg} / \mathrm{mL})$.

\section{MWT}

All the major echocardiographic parameters were significantly associated with 6MWT performance.

The total distance walked in 6MWT was also significantly associated with ventricular function as per the 2016 or 2009 classifications (and specifically with DD versus PVF), with "any ventricular dysfunction" and "HFpEF risk".

\section{Cardiovascular events}

During a mean follow-up time of $2.8 \pm 0.6$ years ( $\min 54$, $\max 1095$ days), only 9 cardiovascular events (cardiovascular death, heart failure or other cardiovascular driven hospitalization) were recorded, without association with ventricular function or with "HFpEF risk".

\section{DISCUSSION}

While SD prevalence was not very different from other studies, DD prevalence of $13 \%$ was lower than what has been reported in other studies, that reported a prevalence of $30-50 \%$ in RA patients versus $25-30 \%$ in the general population[7, 27]. However, the real conundrum lies on the absence of a gold-standard and consensual definition of DD. Different definitions of DD were used across studies and in most cases the presence of one DD parameter was sufficient.

Most previous studies used the 2009 guidelines [21], but their application is complex and different authors applied distinct algorithms. Our study also supports the idea that 2009 guidelines have a poor agreement with 2016 classification [28]. Using the 2009 guidelines instead of the 2016 recommendations, the proportion of DD would have risen from $13 \%$ to $23 \%$, while IDF would be found in $47 \%$ of patients instead of $11 \%$. Invasive studies suggested that the 2016 guidelines are more specific [29]. 
Even when using the same 2016 guidelines, the application of those recommendations and the number of parameters taken into consideration differs amongst studies, which can lead to a significant discrepancy of the reported prevalence of DD [30].

Comparing our results with another study conducted on a similar population except for RA and also using the 2016 guidelines, the prevalence of DD was higher in RA compared with the general population (13\% vs $1.4 \%$ ) [28].

Using 2016 guidelines, diastolic function can be considered normal or abnormal if $>50 \%$ of the available variables (and not necessarily 3 out of 4 ) are normal or abnormal, respectively. Therefore, we considered that 3 parameters were enough to classify diastolic function, but patients with less than 3 parameters had to be excluded.

In our study, the fact that TR velocity could not be properly assessed in more than half of the patients played an important role in the determination of ventricular function. In such cases, other parameters - such as pulmonary vein flow, S' velocity, E/A with Valsalva, atrial longitudinal strain, global left ventricular longitudinal strain and stress echocardiography can be used, but when applied to a large-scale screening program it is unrealistic to use a non-standardized classification.

Therefore, none of the patients with only 3 available parameters could be classified with IDF and patients with only 2 abnormal parameters out of 3 were classified with DD (even though one could argue that in patients without significant tricuspid regurgitation it is unlikely that the pulmonary pressures are increased). If we had considered that 3 abnormal parameters were needed to classify DD, then the number of DD would be much lower and that of IDF much higher. Unfortunately, most authors using 2016 guidelines do not specify how they classified participants.

One could also argue that in patients with some ventricular hypertrophy a different algorithm proposed for myocardial disease in 2016 guidelines [22] could have been applied, but this was not done in other studies either.

Also, in the elderly, normal echocardiographic parameters are different from a younger population and both 2009 and 2016 classifications do not contemplate that.

In our sample, we found $13 \%$ of the patients with HFpEF features according to the 2016 European criteria[20], but interestingly their matching with ventricular dysfunction categories was weak. The terms DD and HFpEF are often used as interchangeable terms, but in fact their overlap is limited.

The echocardiographic parameters most frequently used to assess diastolic function or structural changes associated with HFpEF were associated with traditional cardiovascular 
risk factors and showed a generally good correlation with prognostic surrogate markers, such as 6MWT, NT-proBNP and even hsTnT.

Given the short follow-up and small number of cardiovascular events, we considered the study underpowered to detect an association between echocardiographic classification and events, albeit the association between ventricular function and surrogate prognostic markers such as 6MWT, NT-proBNP and hsTnT. However, most patients with ventricular dysfunction presented NT-proBNP and hsTnT levels within the normal range, and therefore difficult to apply in clinical practice; moreover, they were also changed in IDF and not specifically in DD or SD.

Overall, we did not find significant associations between characteristics of RA disease and echocardiographic parameters. However, inflammatory markers, particularly ESR, had a significant association with most echo findings (and also with outcomes), suggesting that inflammatory pathways may play a role in the development of cardiovascular diseases in these patients.

\section{Limitations}

We acknowledge that our study has several limitations, besides those intrinsic to the definition of DD as already mentioned. Even though it was performed prospectively, data collection was grossly cross-sectional and follow-up was short. Due to its observational nature, we cannot infer causality, but only associations. Considering the relatively low prevalence of systolic and diastolic dysfunction and our sample size, it was probably underpowered to detect independent predictors of SD and DD. Also, without a control group, we cannot be certain if the prevalence of ventricular dysfunction we found in RA patients was significantly different from individuals from the general population that matched other characteristics except for RA - however, we compared the results with a similar population without RA [28].

We did not explore different grades of diastolic dysfunction, given the reduced group size. The most common operational definition for systolic impairment was used, but it is possible that patients with LVEF $>50 \%$ also have systolic dysfunction. We did not evaluate other echocardiographic parameters yet, such as global longitudinal strain, that can detect early systolic ventricular dysfunction - however, this would make screening much more cumbersome and there are no recommendations on how to handle changes in ventricular mechanics in the absence of systolic or diastolic dysfunction.

\section{Conclusions}


In our sample of RA patients without known cardiac disease, the prevalence of subclinical systolic or diastolic dysfunction was $17 \%$ and age stood out as the most important independent predictor of ventricular function in these patients. Therefore, a screening strategy using TTE may be useful in older RA patients, particularly above 57 years.

For the future, our intention is to continue the follow-up of these patients, particularly those with indeterminate diastolic function, to ascertain what is their evolution and prognosis. In fact, we believe that our ongoing search of the optimal echocardiographic identification of diastolic dysfunction has to be guided by clinical outcomes. 


\section{REFERENCES}

1. Solomon DH, Karlson EW, Rimm EB, Cannuscio CC, Mandl LA, Manson JE, Stampfer MJ, Curhan GC. Cardiovascular morbidity and mortality in women diagnosed with rheumatoid arthritis. Circulation, 2003. 107(9): p. 1303-7.

2. Giles JT, Fernandes V, Lima JA, Bathon JM. Myocardial dysfunction in rheumatoid arthritis: epidemiology and pathogenesis. Arthritis Res Ther, 2005. 7(5): p. 195-207.

3. Pujades-Rodriguez M, Duyx B, Thomas SL, Stogiannis D, Rahman A, Smeeth L, Hemingway $H$. Rheumatoid Arthritis and Incidence of Twelve Initial Presentations of Cardiovascular Disease: $A$ Population Record-Linkage Cohort Study in England. PLoS One, 2016. 11(3): p. e0151245.

4. Agca R, Heslinga SC, Rollefstad S, Heslinga M, Mclnnes IB, Peters MJ, Kvien TK, Dougados M, Radner $H$, Atzeni F, Primdahl J, Södergren A, Wallberg Jonsson S, van Rompay J, Zabalan C, Pedersen TR, Jacobsson L, de Vlam K, Gonzalez-Gay MA, Semb AG, Kitas GD, Smulders YM, Szekanecz Z, Sattar N, Symmons DP, Nurmohamed MT. EULAR recommendations for cardiovascular disease risk management in patients with rheumatoid arthritis and other forms of inflammatory joint disorders: 2015/2016 update. Ann Rheum Dis, 2017. 76(1): p. 17-28.

5. Gabriel SE, Crowson CS, O'Fallon WM. Comorbidity in arthritis. J Rheumatol, 1999. 26(11): p. 2475-9.

6. Nicola PJ, Maradit-Kremers H, Roger VL, Jacobsen SJ, Crowson CS, Ballman KV, Gabriel SE. The risk of congestive heart failure in rheumatoid arthritis: a population-based study over 46 years. Arthritis Rheum, 2005. 52(2): p. 412-20.

7. Sharma A, Kaushik R, Kaushik RM, Kakkar R. Echocardiographic evaluation of diastolic dysfunction in rheumatoid arthritis - a case-control study. Mod Rheumatol, 2015. 25(4): p. 552-7.

8. Myasoedova E, Davis JM 3rd, Crowson CS, Roger VL, Karon BL, Borgeson DD, Therneau TM, Matteson EL, Rodeheffer RJ, Gabriel SE. Brief report: rheumatoid arthritis is associated with left ventricular concentric remodeling: results of a population-based cross-sectional study. Arthritis Rheum, 2013. 65(7): p. 1713-8.

9. Mavrogeni S, Karabela G, Stavropoulos E, Gialafos E, Sfendouraki E, Kyrou L, Kolovou G. Imaging patterns of heart failure in rheumatoid arthritis evaluated by cardiovascular magnetic resonance. Int J Cardiol, 2013. 168(4): p. 4333-5.

10. Barbhaiya M, Solomon D. Rheumatoid Arthritis and Cardiovascular Disease: Update on Treatment Issues. Curr Opin Rheumatol, 2013. 25(3): p. 317-324.

11. Roubille C, Richer V, Starnino T, McCourt C, McFarlane A, Fleming P, Siu S, Kraft J, Lynde C, Pope J, Gulliver W, Keeling S, Dutz J, Bessette L, Bissonnette R, Haraoui B. The effects of tumour necrosis factor inhibitors, methotrexate, non-steroidal anti-inflammatory drugs and corticosteroids on cardiovascular events in rheumatoid arthritis, psoriasis and psoriatic arthritis: a systematic review and meta-analysis. Ann Rheum Dis, 2015. 74(3): p. 480-9.

12. Javed Q, Murtaza I. Therapeutic potential of tumour necrosis factor-alpha antagonists in patients with chronic heart failure. Heart Lung Circ, 2013. 22(5): p. 323-7.

13. Sarzi-Puttini P, Atzeni F, Shoenfeld Y, Ferraccioli G. TNF-alpha, rheumatoid arthritis, and heart failure: a rheumatological dilemma. Autoimmun Rev, 2005. 4(3): p. 153-61.

14. Davis JM 3rd, Roger VL, Crowson CS, Kremers HM, Therneau TM, Gabriel SE. The presentation and outcome of heart failure in patients with rheumatoid arthritis differs from that in the general population. Arthritis Rheum, 2008. 58(9): p. 2603-11.

15. Provan S, Angel K, Semb AG, Atar D, Kvien TK. NT-proBNP predicts mortality in patients with rheumatoid arthritis: results from 10-year follow-up of the EURIDISS study. Ann Rheum Dis, 2010. 69(11): p. 1946-50.

16. Myasoedova E, Crowson CS, Nicola PJ, Maradit-Kremers H, Davis JM 3rd, Roger VL, Therneau TM, Gabriel SE. The influence of rheumatoid arthritis disease characteristics on heart failure. J Rheumatol, 2011. 38(8): p. 1601-6. 
17. Liang KP, Kremers HM, Crowson CS, Snyder MR, Therneau TM, Roger VL, Gabriel SE. Autoantibodies and the risk of cardiovascular events. J Rheumatol, 2009. 36(11): p. 2462-9.

18. Geraldino-Pardilla L, Russo C, Sokolove J, Robinson WH, Zartoshti A, Van Eyk J, Fert-Bober J, Lima J, Giles JT, Bathon JM. Association of anti-citrullinated protein or peptide antibodies with left ventricular structure and function in rheumatoid arthritis. Rheumatology (Oxford), 2017. 56(4): p. 534-40.

19. Bradham WS, Bian A, Oeser A, Gebretsadik T, Shintani A, Solus J, Estis J, Lu QA, Todd J, Raggi P, Stein CM. High-sensitivity cardiac troponin-I is elevated in patients with rheumatoid arthritis, independent of cardiovascular risk factors and inflammation. PLoS One, 2012. 7(6): p. e38930.

20. Ponikowski P, Voors AA, Anker SD, Bueno H, Cleland JG, Coats AJ, Falk V, González-Juanatey JR, Harjola VP, Jankowska EA, Jessup M, Linde C, Nihoyannopoulos P, Parissis JT, Pieske B, Riley JP, Rosano GM, Ruilope LM, Ruschitzka F, Rutten FH, van der Meer P; Authors/Task Force Members; Document Reviewers. 2016 ESC Guidelines for the diagnosis and treatment of acute and chronic heart failure: The Task Force for the diagnosis and treatment of acute and chronic heart failure of the European Society of Cardiology (ESC). Developed with the special contribution of the Heart Failure Association (HFA) of the ESC. Eur J Heart Fail, 2016. 18(8): p. 891-975.

21. Nagueh SF, Appleton CP, Gillebert TC, Marino PN, Oh JK, Smiseth OA, Waggoner AD, Flachskampf FA, Pellikka PA, Evangelista A. Recommendations for the evaluation of left ventricular diastolic function by echocardiography. J Am Soc Echocardiogr, 2009. 22(2): p. 107-33.

22. Nagueh SF, Smiseth OA, Appleton CP, Byrd BF 3rd, Dokainish H, Edvardsen T, Flachskampf FA, Gillebert TC, Klein AL, Lancellotti P, Marino P, Oh JK, Popescu BA, Waggoner AD. Recommendations for the Evaluation of Left Ventricular Diastolic Function by Echocardiography: An Update from the American Society of Echocardiography and the European Association of Cardiovascular Imaging. J Am Soc Echocardiogr, 2016. 29(4): p. 277-314.

23. Villeneuve E, Nam J, Emery P. 2010 ACR-EULAR classification criteria for rheumatoid arthritis. Rev Bras Reumatol, 2010. 50(5): p. 481-3.

24. Prevoo ML, van 't Hof MA, Kuper HH, van Leeuwen MA, van de Putte LB, van Riel PL. Modified disease activity scores that include twenty-eight-joint counts. Development and validation in a prospective longitudinal study of patients with rheumatoid arthritis. Arthritis Rheum, 1995. 38(1): p. 44-8.

25. Lang RM, Badano LP, Mor-Avi V, Afilalo J, Armstrong A, Ernande L, Flachskampf FA, Foster E, Goldstein SA, Kuznetsova T, Lancellotti P, Muraru D, Picard MH, Rietzschel ER, Rudski L, Spencer KT, Tsang W, Voigt JU. Recommendations for cardiac chamber quantification by echocardiography in adults: an update from the American Society of Echocardiography and the European Association of Cardiovascular Imaging. Eur Heart J Cardiovasc Imaging, 2015. 16(3): p. 233-70.

26. ATS Committee on Proficiency Standards for Clinical Pulmonary Function Laboratories. ATS statement: guidelines for the six-minute walk test. Am J Respir Crit Care Med, 2002. 166(1): p. 111-7.

27. Aslam F, Bandeali SJ, Khan NA, Alam M. Diastolic dysfunction in rheumatoid arthritis: a meta-analysis and systematic review. Arthritis Care Res (Hoboken), 2013. 65(4): p. 534-43.

28. Almeida JG, Fontes-Carvalho R, Sampaio F, Ribeiro J, Bettencourt P, Flachskampf FA, Leite-Moreira A, Azevedo A. Impact of the 2016 ASE/EACVI recommendations on the prevalence of diastolic dysfunction in the general population. Eur Heart J Cardiovasc Imaging, 2018. 19(4): p. 380-6.

29. Balaney B, Medvedofsky D, Mediratta A, Singh A, Ciszek B, Kruse E, Shah AP, Addetia K, Lang RM, Mor-Avi V. Invasive Validation of the Echocardiographic Assessment of Left Ventricular Filling Pressures Using the 2016 Diastolic Guidelines: Head-to-Head Comparison with the 2009 Guidelines. J Am Soc Echocardiogr, 2018. 31(1): p. 79-88.

30. Selmeryd J, Henriksen E, Leppert J, Hedberg P. Interstudy heterogeneity of definitions of diastolic dysfunction severely affects reported prevalence. Eur Heart J Cardiovasc Imaging, 2016. 17(8): p. 8929. 


\section{TABLES}

Table 1 - Patients' characteristics according to the presence of any signs of ventricular dysfunction

\begin{tabular}{|c|c|c|c|c|}
\hline & $\begin{array}{c}\text { Total } \\
(n=319)\end{array}$ & $\begin{array}{c}\text { Preserved } \\
\text { ventricular } \\
\text { function } \\
(n=232)\end{array}$ & $\begin{array}{c}\text { Any } \\
\text { ventricular } \\
\text { dysfunction } \\
(n=87)\end{array}$ & $p$ value \\
\hline Age, years & $58(19)$ & $55(19)$ & $65(12)$ & $<0.001$ \\
\hline Sex (male), $\mathrm{n}(\%)$ & 70 (22\%) & $51(22 \%)$ & 19 (27\%) & 0.978 \\
\hline $\begin{array}{l}\text { Diabetes mellitus, } \\
\mathrm{n}(\%)\end{array}$ & $37(12 \%)$ & $28(12 \%)$ & $9(24 \%)$ & 0.669 \\
\hline Hypertension, $\mathrm{n}(\%)$ & $136(43 \%)$ & 87 (38\%) & $49(56 \%)$ & 0.003 \\
\hline $\begin{array}{l}\text { Systolic } \quad \text { blood } \\
\text { pressure, } \mathrm{mmHg}\end{array}$ & $130(23)$ & $128(24)$ & $135(22)$ & $<0.001$ \\
\hline $\begin{array}{l}\text { Diastolic blood } \\
\text { pressure, } \mathrm{mmHg}\end{array}$ & $76 \pm 10$ & $75 \pm 11$ & $78 \pm 8$ & 0.050 \\
\hline Heart rate, bpm & $78(18)$ & $78(19)$ & $75(77)$ & 0.477 \\
\hline Smoking $^{\#}, \mathrm{n}(\%)$ & $111(35 \%)$ & $83(36 \%)$ & $28(32 \%)$ & 0.549 \\
\hline $\begin{array}{l}\text { Dyslipidaemia, } \\
\mathrm{n}(\%)\end{array}$ & $146(46 \%)$ & $94(41 \%)$ & $52(60 \%)$ & 0.002 \\
\hline BMI, $\mathrm{kg} / \mathrm{m}^{2}$ & $26(6)$ & $26(6)$ & $27(6)$ & 0.272 \\
\hline $\begin{array}{l}\text { Obesity (BMI } \geq 30) \\
n(\%)\end{array}$ & $63(20 \%)$ & 47 (20\%) & $16(18 \%)$ & 0.709 \\
\hline $\begin{array}{l}\text { Chronic kidney } \\
\text { failure, } \mathrm{n}(\%)\end{array}$ & $10(3)$ & $6(3 \%)$ & $4(5 \%)$ & 0.365 \\
\hline COPD, n (\%) & $16(5 \%)$ & $14(6 \%)$ & $2(2 \%)$ & 0.190 \\
\hline $\begin{array}{l}\text { Family history of } \\
\text { ischemic } \\
\text { cardiovascular } \\
\text { disease, } \mathrm{n}(\%)\end{array}$ & $48(15 \%)$ & $39(17 \%)$ & $9(10 \%)$ & 0.154 \\
\hline $\begin{array}{l}\text { Cardiovascular } \\
\text { medication, } \\
\mathrm{n}(\%)\end{array}$ & & & & \\
\hline ACEI or ARB & $111(35 \%)$ & $69(30 \%)$ & $42(48 \%)$ & 0.002 \\
\hline Beta blocker & $19(6 \%)$ & $11(5 \%)$ & $8(9 \%)$ & 0.141 \\
\hline Thiazide & $49(15 \%)$ & $30(13 \%)$ & 19 (22\%) & 0.052 \\
\hline Loop diuretic & $5(2 \%)$ & $5(2 \%)$ & 0 & - \\
\hline MRA & $1(0.3 \%)$ & 0 & 0 & - \\
\hline ССВ & $30(9 \%)$ & $19(8 \%)$ & $11(13 \%)$ & 0.228 \\
\hline
\end{tabular}




\begin{tabular}{|c|c|c|c|c|}
\hline Statin & $114(36 \%)$ & $71(31 \%)$ & $43(49 \%)$ & 0.002 \\
\hline RA duration, years & $8(13)$ & 7 (13) & $9(12)$ & 0.325 \\
\hline DAS28-ESR & $2.6(1.5)$ & $2.5(1.6)$ & $2.8(1.3)$ & 0.482 \\
\hline \multicolumn{5}{|l|}{$\begin{array}{ll}\mathbf{R A} & \text { medication }^{\S}, \\
\mathrm{n}(\%) & \end{array}$} \\
\hline NSAIDS & 85 (27\%) & $58(25 \%)$ & 27 (31\%) & 0.279 \\
\hline Corticosteroids & $136(43 \%)$ & $91(39 \%)$ & 45 (52\%) & 0.045 \\
\hline Methotrexate & 197 (62\%) & $146(63 \%)$ & $51(59 \%)$ & 0.554 \\
\hline Biologics & $61(19 \%)$ & $50(22 \%)$ & $11(13 \%)$ & 0.075 \\
\hline Other drugs & $129(40 \%)$ & $93(41 \%)$ & $34(39 \%)$ & 0.762 \\
\hline \multicolumn{5}{|l|}{ Biomarkers } \\
\hline $\begin{array}{l}\text { NT-proBNP, } \\
\mathrm{pg} / \mathrm{mL}\end{array}$ & $\begin{array}{l}75 \\
(94)\end{array}$ & $68(84)$ & $103(141)$ & 0.008 \\
\hline $\begin{array}{l}\text { hs-troponin T, } \\
\text { ng/mL }\end{array}$ & $\begin{array}{c}0.004 \\
(0.005)\end{array}$ & $0.003(0.004)$ & $0.005(0.004)$ & 0.236 \\
\hline $\begin{array}{l}\text { ESR, } \\
\text { mm }\end{array}$ & $20(25)$ & $20(22)$ & $21(28)$ & 0.260 \\
\hline $\begin{array}{l}\text { CRP, } \\
\quad \mathrm{mg} / \mathrm{dl}\end{array}$ & $3.0(6.4)$ & $3.0(6.4)$ & $3.3(6.9)$ & 0.361 \\
\hline $\begin{array}{l}\text { eGFR, } \\
\mathrm{mL} / \mathrm{min} / 1.73 \mathrm{~m}^{2}\end{array}$ & $93(27)$ & $95(28)$ & $90(26)$ & 0.010 \\
\hline $\begin{array}{l}\begin{array}{l}\text { Anti-CCP } \\
n(\%)\end{array} \\
n(\%) \text {, }\end{array}$ & $249(78 \%)$ & $185(80 \%)$ & $64(74 \%)$ & 0.236 \\
\hline $\begin{array}{l}\text { Distance in } 6 \mathrm{MWT} \text {, } \\
\mathrm{m}\end{array}$ & $390(105)$ & $390(90)$ & $360(86)$ & 0.001 \\
\hline
\end{tabular}

Legend: $A C E i$ - angiotensin-converting enzyme inhibitor. Anti-CCP + - positive for anti-cyclic citrullinated peptide antibodies. ARB - angiotensin receptor blocker. BMI-body mass index. CCB calcium channel blocker. COPD - chronic obstructive pulmonary disease. CRP - C-reactive protein. DAS28 - Disease Activity Score 28; eGFR - estimated glomerular filtration rate; ESR - erythrocyte sedimentation rate. MRA - mineralocorticoid receptor antagonist. RA - rheumatoid arthritis. $R F+-$ positive for rheumatoid factor. 6MWT - 6-minute walk test (distance in meters).

Ventricular function was classified as per 2016 guidelines. Patients in any category of ventricular dysfunction (systolic, diastolic or indeterminate) were categorized as "any ventricular dysfunction" and all the others as "preserved ventricular function".

Continuous variables are represented as mean \pm standard deviation or as median (75-25 interquartile range), according to their gaussian or non-gaussian distribution, respectively.

${ }^{\#}$ Current or previous smoking habits were considered.

$\S$ More than one medication per patient was allowed.

Values of blood pressure and heart rate were obtained when patients were enrolled. 
Table 2 - Patients' characteristics according to categories of ventricular function

\begin{tabular}{|c|c|c|c|c|c|c|}
\hline & $\begin{array}{c}\text { Total } \\
(n=319)\end{array}$ & $\begin{array}{l}\text { Preserved } \\
\text { ventricular } \\
\text { function } \\
(n=232)\end{array}$ & $\begin{array}{c}\text { Indeterminate } \\
\text { diastolic } \\
\text { function } \\
(n=34)\end{array}$ & $\begin{array}{c}\text { Isolated } \\
\text { diastolic } \\
\text { dysfunction } \\
(n=40)\end{array}$ & $\begin{array}{l}\text { Systolic ( } \pm \\
\text { diastolic) } \\
\text { dysfunction } \\
(n=13)\end{array}$ & $p$ value \\
\hline Age, years & $58(19)$ & $55(19)$ & $\begin{array}{c}63(12) \\
p<0.001\end{array}$ & $\begin{array}{c}67(12) \\
p<0.001\end{array}$ & $\begin{array}{c}59(16) \\
p=0.263\end{array}$ & $<0.001$ \\
\hline $\begin{array}{ll}\text { Sex } & \text { (male), } \\
\text { n(\%) }\end{array}$ & $\begin{array}{c}70 \\
(22 \%) \\
\end{array}$ & $51(22 \%)$ & $\begin{array}{l}5(15 \%) \\
p=0.328\end{array}$ & $\begin{array}{l}8(20 \%) \\
p=0.764\end{array}$ & $\begin{array}{l}6(46 \%) \\
p=0.056\end{array}$ & 0.140 \\
\hline $\begin{array}{l}\text { Diabetes } \\
\text { mellitus, n (\%) }\end{array}$ & $\begin{array}{c}37 \\
(12 \%)\end{array}$ & 28 (12\%) & $\begin{array}{c}3(9 \%) \\
p=0.597\end{array}$ & $\begin{array}{l}4(10 \%) \\
p=0.724\end{array}$ & $\begin{array}{l}2(15 \%) \\
p=0.713\end{array}$ & 0.900 \\
\hline $\begin{array}{l}\text { Hypertension, } \\
\text { n (\%) }\end{array}$ & $\begin{array}{c}136 \\
(43 \%)\end{array}$ & $87(38 \%)$ & $\begin{array}{l}23(68 \%) \\
p=0.001\end{array}$ & $\begin{array}{l}20(50 \%) \\
p=0.115\end{array}$ & $\begin{array}{l}6(46 \%) \\
p=0.496\end{array}$ & 0.005 \\
\hline $\begin{array}{l}\text { Systolic blood } \\
\text { pressure, } \\
\text { mmHg }\end{array}$ & $\begin{array}{l}130 \\
(23)\end{array}$ & $128(24)$ & $\begin{array}{l}136(21) \\
p=0.010\end{array}$ & $\begin{array}{l}134(23) \\
\mathbf{p}=\mathbf{0 . 0 0 3}\end{array}$ & $\begin{array}{l}136(23) \\
p=0.219\end{array}$ & 0.004 \\
\hline $\begin{array}{l}\text { Diastolic blood } \\
\text { pressure, } \\
\text { mmHg }\end{array}$ & $76 \pm 10$ & $75 \pm 11$ & $\begin{array}{c}76 \pm 7 \\
p=0.595\end{array}$ & $\begin{array}{c}78 \pm 8 \\
p=0.096\end{array}$ & $\begin{array}{l}81 \pm 11 \\
p=0.045\end{array}$ & 0.067 \\
\hline Heart rate, bpm & $78(18)$ & 78 (19) & $\begin{array}{l}75(11) \\
p=0.394\end{array}$ & $\begin{array}{c}76(17) \\
p=0.270\end{array}$ & $\begin{array}{c}79(30) \\
p=0.156\end{array}$ & 0.340 \\
\hline $\begin{array}{l}\text { Smoking }{ }^{\#}, \quad \mathrm{n} \\
(\%)\end{array}$ & $\begin{array}{c}111 \\
(35 \%)\end{array}$ & $83(36 \%)$ & $\begin{array}{l}12(35 \%) \\
p=0.991\end{array}$ & $\begin{array}{l}9(22 \%) \\
p=0.115\end{array}$ & $\begin{array}{l}7(54 \%) \\
p=0.188\end{array}$ & 0.190 \\
\hline $\begin{array}{l}\text { Dyslipidaemia, } \\
\text { n (\%) }\end{array}$ & $\begin{array}{c}146 \\
(46 \%)\end{array}$ & $94(41 \%)$ & $\begin{array}{l}19(56 \%) \\
p=0.099\end{array}$ & $\begin{array}{l}26(65 \%) \\
p=0.005\end{array}$ & $\begin{array}{l}7(54 \%) \\
p=0.354\end{array}$ & 0.018 \\
\hline BMI, $\mathrm{kg} / \mathrm{m}^{2}$ & $26(6)$ & $26(6)$ & $\begin{array}{c}26(5) \\
p=0.622\end{array}$ & $\begin{array}{c}28(6) \\
p=0.120\end{array}$ & $\begin{array}{c}26(5) \\
p=0.874\end{array}$ & 0.289 \\
\hline $\begin{array}{l}\text { Obesity } \\
\geq 30), n(\%)\end{array}$ & $\begin{array}{c}63 \\
(20 \%)\end{array}$ & $47(20 \%)$ & $\begin{array}{l}4(12 \%) \\
p=0.310\end{array}$ & $\begin{array}{l}10(25 \%) \\
p=0.385\end{array}$ & $\begin{array}{l}2(15 \%) \\
p=0.745\end{array}$ & 0.530 \\
\hline $\begin{array}{l}\text { Chronic kidney } \\
\text { failure, } n(\%)\end{array}$ & $10(3)$ & $6(3 \%)$ & $\begin{array}{c}1(3 \%) \\
p=0.923\end{array}$ & $\begin{array}{c}2(5 \%) \\
p=0.431\end{array}$ & $\begin{array}{c}1(8 \%) \\
p=0.319\end{array}$ & 0.680 \\
\hline COPD, n(\%) & $16(5 \%)$ & $14(6 \%)$ & 0 & $\begin{array}{c}2(5 \%) \\
p=0.770\end{array}$ & 0 & 0.380 \\
\hline $\begin{array}{l}\text { Family history } \\
\text { of ischemic } \\
\text { cardiovascular } \\
\text { disease, } \mathrm{n}(\%)\end{array}$ & $\begin{array}{c}48 \\
(15 \%)\end{array}$ & 39 (17\%) & $\begin{array}{l}6(18 \%) \\
p=0.955\end{array}$ & $\begin{array}{c}1(3 \%) \\
p=0.041\end{array}$ & $\begin{array}{l}2(15 \%) \\
p=0.862\end{array}$ & 0.120 \\
\hline \multicolumn{7}{|l|}{$\begin{array}{l}\text { Cardiovascular } \\
\text { medication, } \\
\text { n (\%) }\end{array}$} \\
\hline ACEi or ARB & $\begin{array}{c}111 \\
(35 \%)\end{array}$ & $69(30 \%)$ & $\begin{array}{l}21(62 \%) \\
p<0.001\end{array}$ & $\begin{array}{l}16(40 \%) \\
p=0.195\end{array}$ & $\begin{array}{l}5(39 \%) \\
p=0.503\end{array}$ & 0.003 \\
\hline Beta blocker & $19(6 \%)$ & $11(5 \%)$ & $\begin{array}{l}4(12 \%) \\
p=0.120\end{array}$ & $\begin{array}{l}4(10 \%) \\
p=0.204\end{array}$ & 0 & 0.220 \\
\hline Thiazide & $\begin{array}{c}49 \\
(15 \%)\end{array}$ & 30 (13\%) & $\begin{array}{l}11(32 \%) \\
p=0.003\end{array}$ & $\begin{array}{l}6(15 \%) \\
p=0.590\end{array}$ & $\begin{array}{l}2(15 \%) \\
p=0.713\end{array}$ & 0.020 \\
\hline
\end{tabular}




\begin{tabular}{|c|c|c|c|c|c|c|}
\hline & & \multirow[b]{2}{*}{$5(2 \%)$} & & \multirow[b]{2}{*}{0} & & \multirow[b]{2}{*}{0.580} \\
\hline Loop diuretic & $5(2 \%)$ & & 0 & & 0 & \\
\hline MRA & $\begin{array}{c}1 \\
(0.3 \%)\end{array}$ & 0 & 0 & 0 & 0 & - \\
\hline ССВ & $30(9 \%)$ & 19 (8\%) & $\begin{array}{l}5(15 \%) \\
p=0.204\end{array}$ & $\begin{array}{l}6(15 \%) \\
p=0.159\end{array}$ & 0 & 0.210 \\
\hline Statin & $\begin{array}{c}114 \\
(36 \%)\end{array}$ & $71(31 \%)$ & $\begin{array}{l}15(44 \%) \\
p=0.118\end{array}$ & $\begin{array}{l}21(52 \%) \\
p=0.008\end{array}$ & $\begin{array}{l}7(54 \%) \\
p=0.089\end{array}$ & 0.015 \\
\hline $\begin{array}{l}\text { RA duration, } \\
\text { years }\end{array}$ & $8(13)$ & $7(13)$ & $\begin{array}{c}9(14) \\
p=0.210\end{array}$ & $\begin{array}{c}11(12) \\
p=0.591\end{array}$ & $\begin{array}{c}6(17) \\
p=0.936\end{array}$ & 0.361 \\
\hline DAS28-ESR & $\begin{array}{c}2.6 \\
(1.5) \\
\end{array}$ & $2.5(1.6)$ & $\begin{array}{l}2.6(1.1) \\
p=0.829\end{array}$ & $\begin{array}{l}3.0(1.2) \\
p=0.482\end{array}$ & $\begin{array}{l}2.9(1.4) \\
p=0.805\end{array}$ & 0.590 \\
\hline $\begin{array}{l}\text { RA } \\
\text { medication }{ }^{\S}, \\
\text { n(\%) }\end{array}$ & & & & & & \\
\hline NSAIDS & $\begin{array}{c}85 \\
(27 \%)\end{array}$ & $58(25 \%)$ & $\begin{array}{l}11(32 \%) \\
p=0.319\end{array}$ & $\begin{array}{l}10(25 \%) \\
p=0.928\end{array}$ & $\begin{array}{l}6(46 \%) \\
p=0.090\end{array}$ & 0.290 \\
\hline Corticosteroids & $\begin{array}{c}136 \\
(43 \%)\end{array}$ & 91 (39\%) & $\begin{array}{l}14(41 \%) \\
p=0.803\end{array}$ & $\begin{array}{l}23(58 \%) \\
p=0.031\end{array}$ & $\begin{array}{l}8(62 \%) \\
p=0.117\end{array}$ & 0.078 \\
\hline Methotrexate & $\begin{array}{c}197 \\
(62 \%)\end{array}$ & $146(63 \%)$ & $\begin{array}{l}17(50 \%) \\
p=0.141\end{array}$ & $\begin{array}{c}28(70 \%) \\
p=0.414\end{array}$ & $\begin{array}{l}6(50 \%) \\
p=0.359\end{array}$ & 0.260 \\
\hline Biologics & $\begin{array}{c}61 \\
(19 \%)\end{array}$ & $50(22 \%)$ & $\begin{array}{l}5(15 \%) \\
p=0.411\end{array}$ & $\begin{array}{l}5(12 \%) \\
p=0.228\end{array}$ & $\begin{array}{c}1(8 \%) \\
p=0.276\end{array}$ & 0.380 \\
\hline Other drugs & $\begin{array}{c}129 \\
(40 \%)\end{array}$ & 93 (41\%) & $\begin{array}{l}16(47 \%) \\
p=0.516\end{array}$ & $\begin{array}{l}13(32 \%) \\
p=0.305\end{array}$ & $\begin{array}{l}5(38 \%) \\
p=0.848\end{array}$ & 0.630 \\
\hline Biomarkers & & & & & & \\
\hline $\begin{array}{l}\text { NT-proBNP, } \\
\text { pg/mL }\end{array}$ & $\begin{array}{c}75 \\
(94)\end{array}$ & $68(84)$ & $\begin{array}{c}120(139) \\
p=0.011\end{array}$ & $\begin{array}{l}90(140) \\
p=0.280\end{array}$ & $\begin{array}{c}107(550) \\
p=0.007\end{array}$ & 0.002 \\
\hline $\begin{array}{l}\text { hs-troponin } \mathrm{T}, \\
\mathrm{ng} / \mathrm{mL}\end{array}$ & $\begin{array}{c}0.004 \\
(0.005)\end{array}$ & $\begin{array}{c}0.003 \\
(0.004)\end{array}$ & $\begin{array}{c}0.005(0.004) \\
p=0.702\end{array}$ & $\begin{array}{c}0.005(0.006) \\
p=0.355\end{array}$ & $\begin{array}{c}0.006(0.002) \\
p=0.183\end{array}$ & $<0.001$ \\
\hline $\begin{array}{l}\text { ESR, } \\
\text { mm }\end{array}$ & $20(25)$ & $20(22)$ & $\begin{array}{c}21(21) \\
p=0.777\end{array}$ & $\begin{array}{c}27(28) \\
p=0.100\end{array}$ & $\begin{array}{c}16(41) \\
p=0.355\end{array}$ & 0.377 \\
\hline $\begin{array}{l}\text { CRP, } \\
\quad \mathrm{mg} / \mathrm{dl}\end{array}$ & $\begin{array}{l}3.0 \\
(6.4) \\
\end{array}$ & $3.0(6.4)$ & $\begin{array}{l}3.2(4.2) \\
p=0.550\end{array}$ & $\begin{array}{l}2.8(6.8) \\
p=0.505\end{array}$ & $\begin{array}{c}11.0(34.1) \\
p=0.029\end{array}$ & 0.098 \\
\hline $\begin{array}{l}\text { eGFR, } \\
\mathrm{mL} / \mathrm{min} / 1.73 \mathrm{~m}^{2}\end{array}$ & $93(27)$ & $95(28)$ & $\begin{array}{c}90(30) \\
p=0.059\end{array}$ & $\begin{array}{c}87(22) \\
p=0.051\end{array}$ & $\begin{array}{c}95(76) \\
p=0.304\end{array}$ & 0.078 \\
\hline $\begin{array}{l}\text { Anti-CCP } \\
\text { RF, } n(\%)\end{array}$ & $\begin{array}{c}249 \\
(78 \%)\end{array}$ & $185(80 \%)$ & $\begin{array}{l}26(77 \%) \\
p=0.671\end{array}$ & $\begin{array}{c}28(70 \%) \\
p=0.177\end{array}$ & $\begin{array}{l}10(77 \%) \\
p=0.813\end{array}$ & 0.590 \\
\hline $\begin{array}{l}\text { Distance } \\
\text { 6MWT, } m\end{array}$ & $\begin{array}{c}390 \\
(105)\end{array}$ & $390(90)$ & $\begin{array}{l}360(75) \\
p=0.006\end{array}$ & $\begin{array}{l}360(90) \\
p=0.007\end{array}$ & $\begin{array}{l}360(98) \\
p=0.153\end{array}$ & $<0.001$ \\
\hline
\end{tabular}

Legend: ACEi - angiotensin-converting enzyme inhibitor. Anti-CCP + - positive for anti-cyclic citrullinated peptide antibodies. ARB - angiotensin receptor blocker. BMI - body mass index. CCB calcium channel blocker. COPD - chronic obstructive pulmonary disease. CRP - C-reactive protein. DAS28 - Disease Activity Score 28; eGFR - estimated glomerular filtration rate; ESR - erythrocyte sedimentation rate. MRA - mineralocorticoid receptor antagonist. $R A-$ rheumatoid arthritis. $R F+-$ positive for rheumatoid factor. 6MWT - 6-minute walk test (distance in meters).

Ventricular function was classified as per 2016 guidelines.

Continuous variables are represented as mean \pm standard deviation or as median (75-25 interquartile range), according to their gaussian or non-gaussian distribution, respectively.

The $p$ value in the right-handside column represents the comparison between the 4 categories of ventricular function; the $p$ value presented under each category refers to the comparison with the reference category (preserved ventricular function). 
\#Current or previous smoking habits were considered.

${ }^{\S}$ More than one medication per patient was allowed.

Values of blood pressure and heart rate were obtained when patients were enrolled.

\section{FIGURES}

Figure 1 - Simplified 2009 and 2016 echocardiographic guidelines for ventricular function classification.

2009 echocardiographic classification

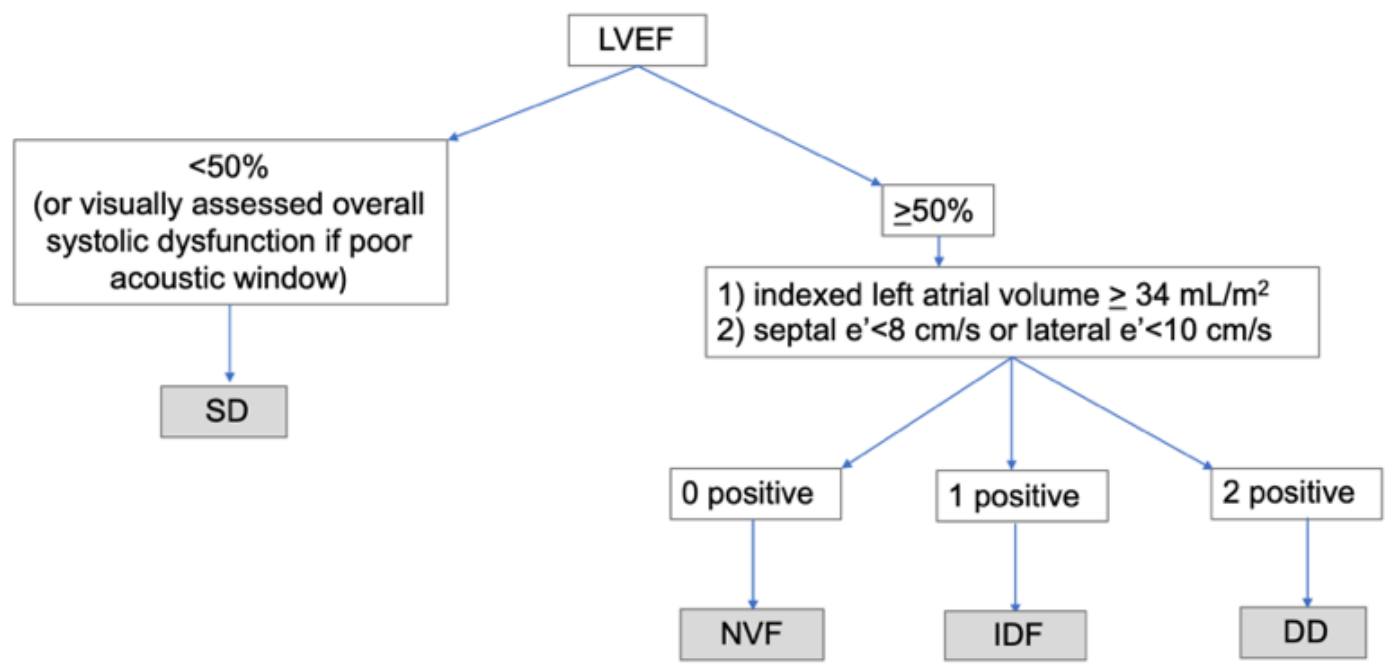

2016 echocardiographic classification

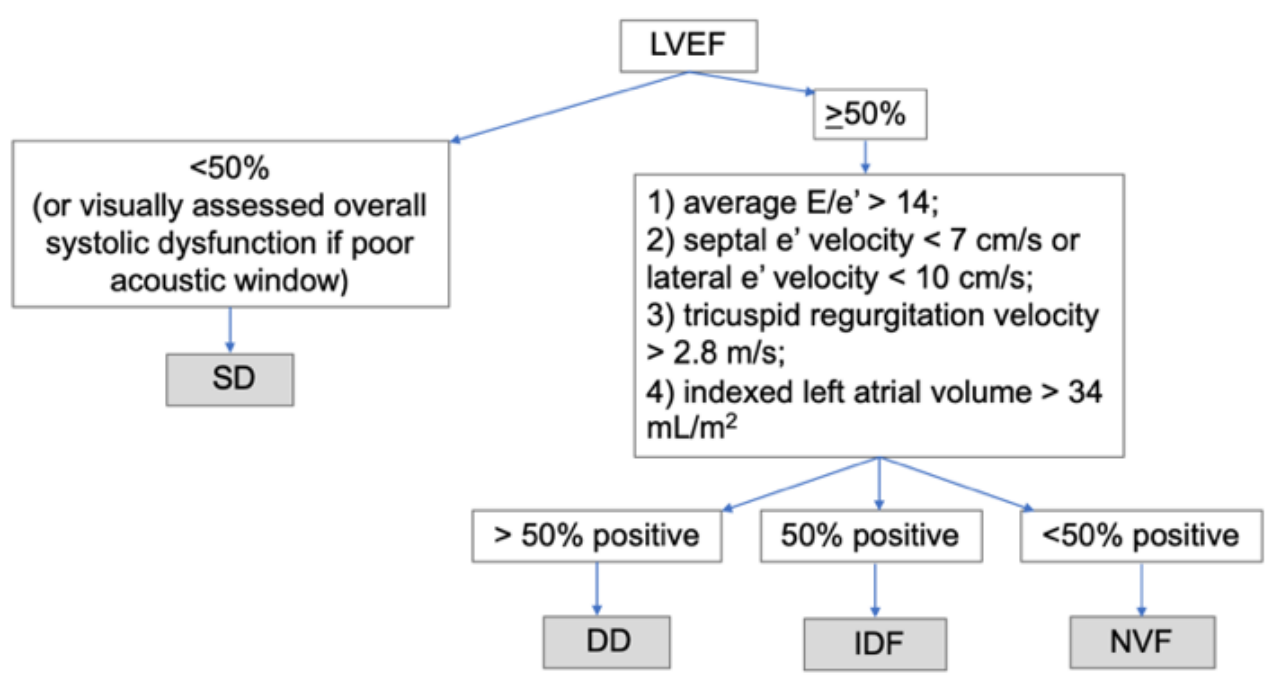

Legend: $D D$ - diastolic dysfunction; IDF - indeterminate diastolic function; NVF - normal ventricular function; $S D$ - systolic dysfunction.

Using 2016 guidelines, if a patient had only 3 parameters available and 2 were abnormal, he/she was 
categorized as having DD, if 2 were normal, as having normal diastolic function. If only 2 or less variables were available, diastolic classification was recorded as missing.

Using 2009 guidelines, it was mandatory that a patient had at least one e' value and indexed LA volume; if one of those variables was missing, diastolic classification was recorded as missing.

Figure 2 - Patients' distribution according to echocardiographic ventricular function categories, according to 2016 and 2009 criteria of diastolic function.
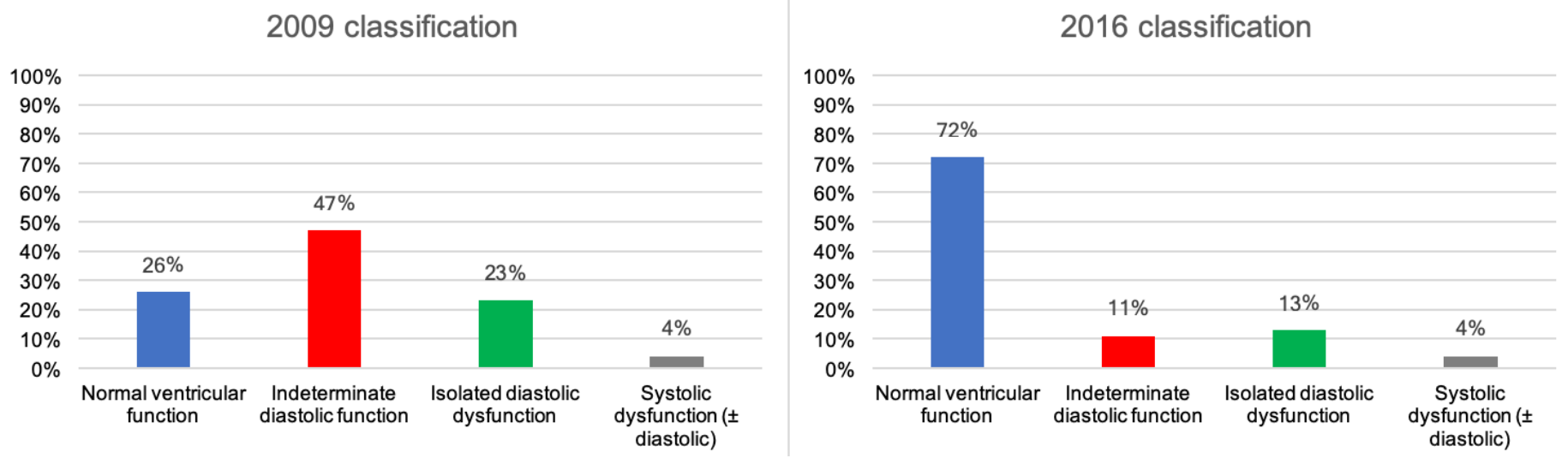